\title{
Gravity satellite data analysis for subsurface modelling in Mount Merapi-Merbabu, Java, Indonesia
}

\author{
Puspita Dian Maghfira ${ }^{1, *}$ and Sintia Windhi Niasari ${ }^{1}$ \\ ${ }^{1}$ Geophysics Sub-Departement Laboratorium, Universitas Gadjah Mada, Yogyakarta, Indonesia
}

\begin{abstract}
Mount Merapi and Mount Merbabu are active volcanoes that lies in Java Island. Java island is part of Indonesia region. This island was subduction product of Eurasian and Indo-Australian plates, caused the island consist of many volcanoes. A regional gravity study was carried out over Mt. Merapi-Merbabu by TOPEX/Poseidon satellite data. The data was corrected by free air correction and become free air anomaly. Then, that anomaly was corrected by Bouguer and Terrain corrections, become Complete-Bouguer Anomaly. This study present subsurface density model beneath Mt. Merapi and Merbabu to identify the magma chamber.
\end{abstract}

\section{Introduction}

Java island lies within the Indonesian archipelago that was subduction product of Eurasian and Indo-Australian plates [1]. The southeastern part of this plates called Sundaland [2]. Because of subduction process, there are many volcanic in Sundaland, so Sundaland is known as volcanic island. Subduction is still active all around southeast Asian archipelago [3]. Subduction activity has been an important influence on geological history [4].

This research aims to identify subsurface structure of the Mount Merapi and Mount Merbabu's magma chamber using gravity method. Gravity method carried out measuring and comparing gravity values at several stations, with various corrections applied to the data [5]. In addition to Earth Tides, latitude, free-air and Bouguer corrections, one must determine the local effect of the surrounding topography on the gravity field. Gravity method can be divided into two measurements i.e., field measurement and satellite measurement. In this research, we used gravity satellite data to identify geological structure, especially magma chamber location of Merapi and Merbabu volcanoes.

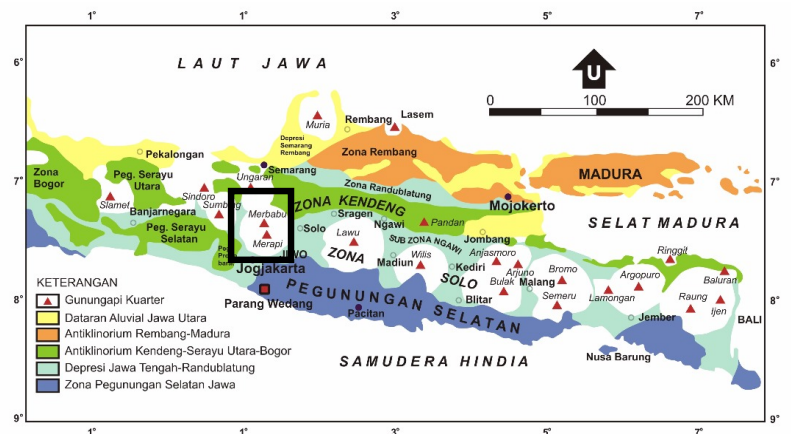

Fig. 1. Physigraphy map of Java by Van Bammelen (1949), black box shows location of the research area

\section{Gravity data}

Gravity method is one of geophysical methods that can be use in many explorations. The gravity method involves measuring the earth's gravitational field at specific locations on the earth's surface to determine the location of subsurface density variations [9]. The earth's gravitational field measured at the earth's surface is affected also by topographic changes, the earth's shape and rotation, and earth tides. Gravity data measurements divided into two methods, i.e. field measurement and satellite measurement. For this study, we used satellite data measurement.

The area of this study is $88 \mathrm{~km}^{2}$ that located in Central Java and Yogyakarta Provinces (Figure 1). This area covering Mount Merapi, Merbabu, and Ungaran in Java. The total number of gravity station was up to 2700 . The data were downloaded at February $23^{\text {rd }}, 2018$ from Topex Satellite's website (http://topex.ucsd.edu/cgibin/get_data.cgi) [6].

Topex is a Geodesy satellite launched by NASA. A satellite altimeter uses a pulse-limited radar to measure the altitude of the satellite above the closest sea surface point to a very high precision [7]. There are two type of the data obtained from topex, i.e. topographic data and gravity field data. The distance of each measurement point is $1.8 \mathrm{~km}$. These gravity data are already Free Air Anomaly. And then, the topographic data were used for terrain correction.

Gravity data that collected from Topex/Poseidon satellite are already free air anomaly. Free Air Anomaly is the measured gravity anomaly after a free air correction is applied to correct for the elevation at which a measurement is made. The free air gravity anomaly has been corrected for the gravity effect caused by the elevation difference between the station and sea level (a

\footnotetext{
* Corresponding author: puspitadianm $@$ gmail.com
} 
correction for distance) and is a standard for oceanic gravity interpretation [5].

Figure 2 shows Free Air Anomaly map in the research area. From the map we can see that high anomaly located in Merapi and Merbabu volcanoes showed gravity value about $115-175 \mathrm{mGal}$. The value of free air anomaly is become lower in eastern and southern of research area. High anomaly in Merapi-Merbabu volcanoes indicate high density in the subsurface.

The Bouguer gravity anomaly has been further corrected for the mass that may exist between sea level and the observer (a correction for mass) and is a standard used in geologic interpretation on land. A CompleteBouguer anomaly (CBA) contains a terrain correction that uses a more complete representation of the local topography, which is necessary for accurate gravity values in mountainous areas [8].

Figure 3 shows Complete Bouguer Anomaly map. From this map, the value of gravity field about -300 $\mathrm{mGal}$ to $300 \mathrm{mGal}$. The high anomaly located in Mount Merapi and Merbabu, then low anomaly located in the eastern part of study area. The area that has high anomaly is also indicate high density of that area. The result is suitable with the other study that Mount MerapiMerapi body has high density than the other rocks around it.

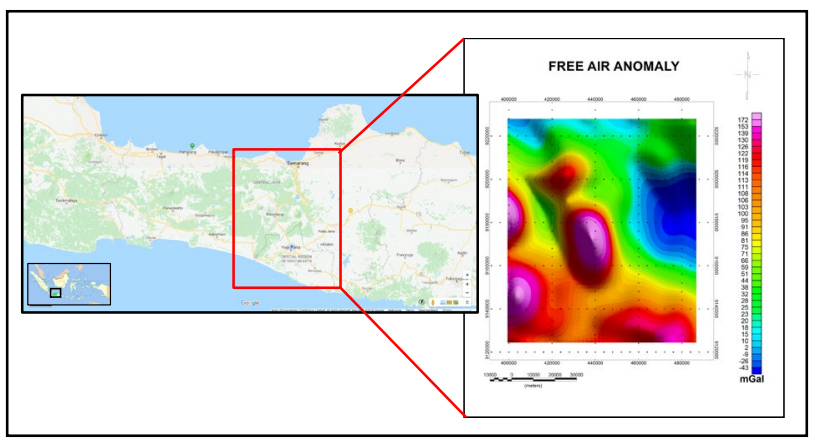

Fig. 2. Free Air Anomaly Map in study area, shows that high anomaly located in Mount Merapi-Merbabu (Google Maps, 2018). The High anomaly indicates high density in that area than the other rocks around Mt.Merapi and Mt.Merbabu.

\section{2-D Modelling}

The new approach of two-dimensional (2D) gravity modelling to separate observed anomalies into a series of spatial components associated with different "depth slices" of density [8]. 2-D gravity modelling run by Geosoft software. The model was made by matching data between field data and model data and then combined with regional geological data. The profile lies along Merapi and Merbabu volcanoes. Subsurface Modelling shows five layers below Mount MerapiMerbabu.

The top layer is pyroclastic rocks, product of Mount Merapi-Merbabu activity [8]. The density value of this layer is $2.15 \mathrm{gr} / \mathrm{cc}$ and $0-500 \mathrm{~m}$ depth. The second layer is similar with the top layer. This layer has higher density than the top layer, is about $2.4 \mathrm{gr} / \mathrm{cc}$. the next layer is interpreted as magma chamber of Mount Merapi and Merbabu. Magma Chamber has density value about 2.6-2.75 $\mathrm{gr} / \mathrm{cc}$. there is difference between Merapi and Merbabu volcanoes. Magma Chamber of Merbabu is denser than Merapi. However, magma chamber of Merapi is shallower than Mount. The fourth layer is basement that has density value about $2.8 \mathrm{gr} / \mathrm{cc}$ in $5-8$ $\mathrm{km}$ depth. the fifth layer has the highest density value, about $3.0 \mathrm{gr} / \mathrm{cc}$.

In addition to these five layers of rock, there is a model of magma chamber in under Merbabu and Merapi volcanoes. The magma chamber of Merbabu has a depth of $4.5 \mathrm{~km}$ below the summit with a density of $2.75 \mathrm{gr} / \mathrm{cc}$. Beneath Merapi, there are 2 magma chambers, with the upper magma chamber at a depth of 500 meters below the summit, and bottom magma chamber at a depth of $3.2 \mathrm{~km}$ below peak. The density of the magma pouch under Merapi is $2.70 \mathrm{gr} / \mathrm{cc}$.

The density of the magma chamber beneath the Mt. Merbabu is higher than magma chamber under Mount Merapi. Both of these can be the answer the question why Mt. Merbabu is more silent than the Mt. Merapi.

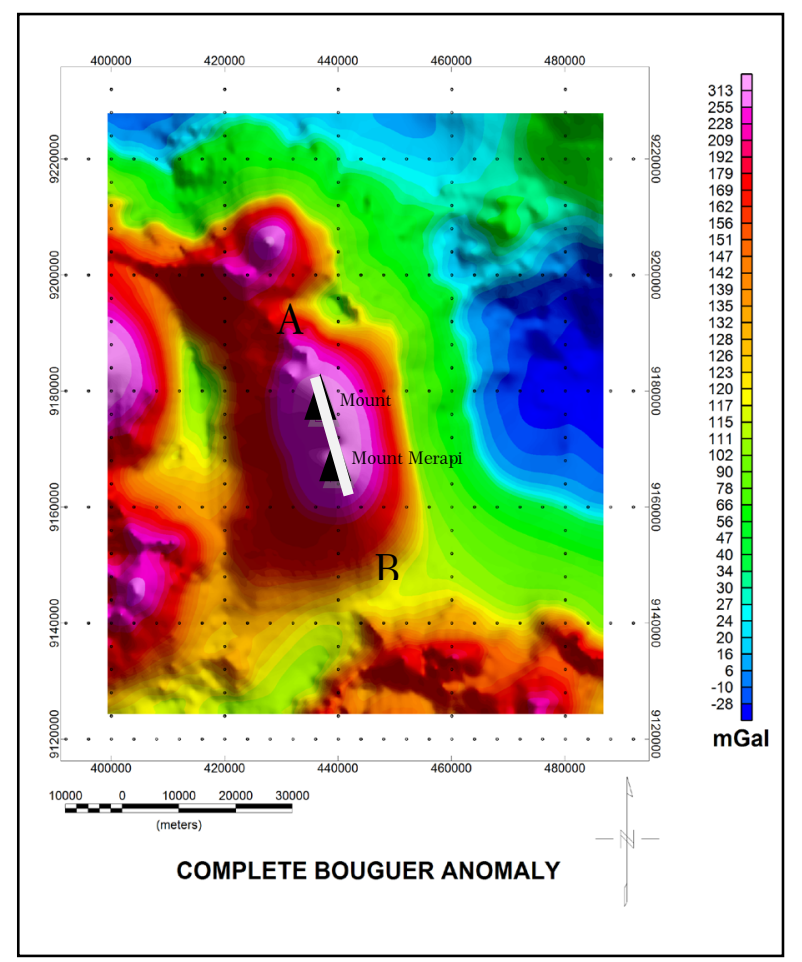

Fig. 3. Complete-Bouger Anomaly Map in study area, shows that high anomaly located in Mount Merapi-Merbabu. The high anomaly indicates high density in that area than the other rocks around Mt.Merapi and Mt.Merbabu. Profile A-B was marked by white line in the map. 


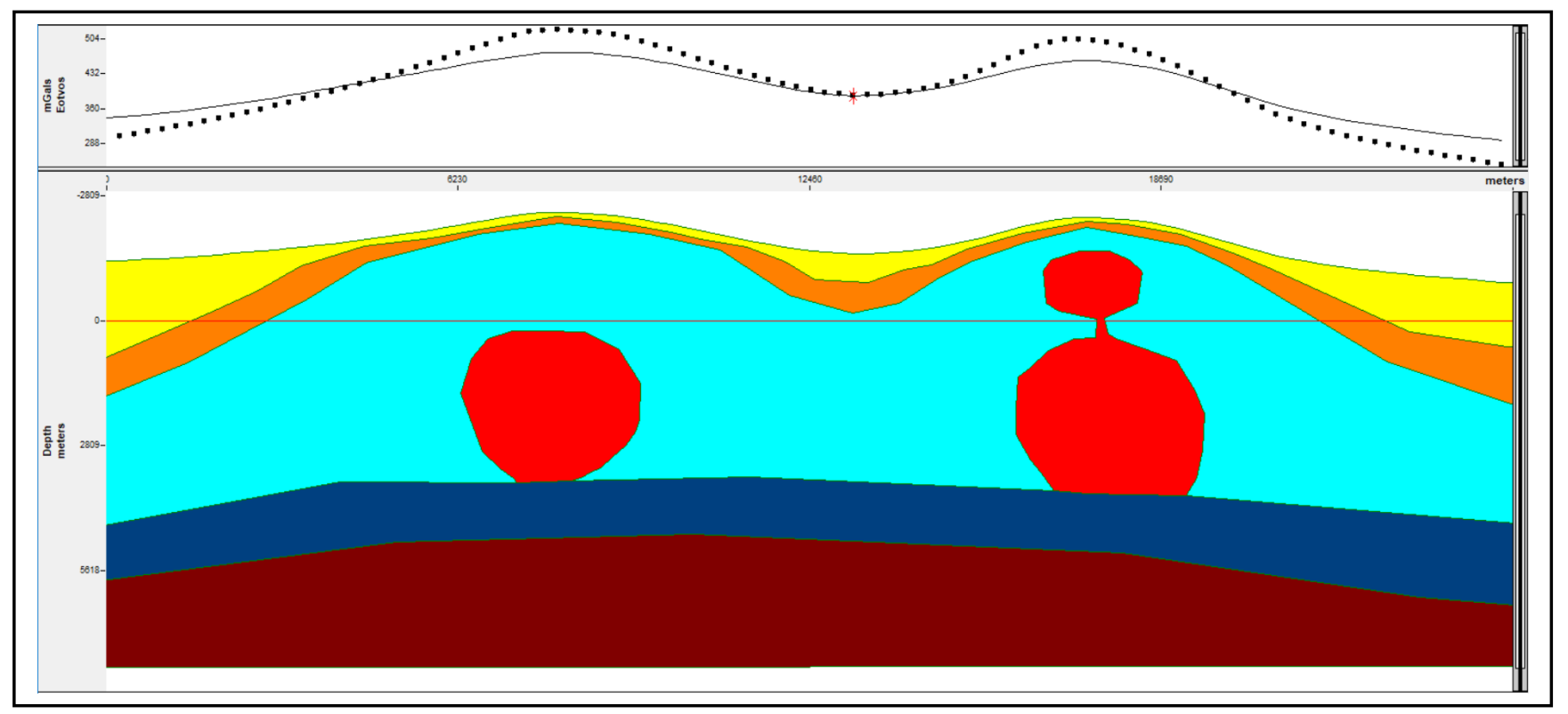

Fig. 4. Modelling cross section along profile A-B in study area. The models shows that density of Mt. Merbabu's magma chamber higher than Mt. Merapi, while magma chamber of Mt. Merapi shallower than Mt. Merbabu.

\section{References}

1. Van Bemmelen, R.W., The Geologi of Indonesia v.IA, General Geologi, Government publisherm The Hague, (1949).

2. W. Hamilton, Tectonics of the Indonesian Region, USGS Professional Paper, vol. 1078, (1979).

3. Clements, B., Hall, R., Smyth, R., and Cottam, A., Thrusting of Vocanic arc: A new Structural Model for Java, Geological Society of London, (1999).

4. Smyth, H.R., Hall, R., Nichols, G.J., Cenozoic volcanic arc history of East Java, Indonesia: The stratigraphic record of eruptions on an active continental margin, The Geological Society of America, (2008)

5. W.M. Telford, L.P. Geldart, and R.E. Sheriff, Applied Geophysics (1990).

6. UCSD, http://topex.ucsd.edu/cgi-bin/get_data.cgi, (2018)

7. USGS, Introduction to potential fields: Gravity, (1997)

8. Soengkono, S., Gravity Modelling of Reporoa Basin Eastern Taupo Volcanic Zone (TVZ), New Zealand, New Zealand Geothermal Workshop 2012 Proceedings, Auckland, (2012).

9. Arsadi, E.M., Suparka, S. and Nishimura, S., Subsurface structure of Merapi inferred form magnetikotelluric, gravimetric and magnetikic surveys, Paper presented at Merapi Decade Volcano International Workshop, (1995).

10. Mickus, K., Gravity Method: Environmental and Engineering Applications, Department of Geosciences, Southwest Missouri State University, Springfield, MO 65804, (1980). 